\title{
Sanal Kaytarma Davranışının İş Performansına Etkisinde İşe Bağlılığın Aracı Rolüne Yönelik Bilişim Sektöründe Bir Araştırma

\author{
(A Research in the Information Sector on the Mediating Role of Work Engagement in the \\ Effect of Cyberloafing Behavior on Work Performance)
}

\author{
Ahmet Tuncay ERDEM iD a \\ a Bolu Abant İzzet Baysal Üniversitesi, İletişim Fakültesi, Bolu, Türkiye. ahmeterdem@ibu.edu.tr
}

\begin{tabular}{|c|c|}
\hline MAKALE BİLGİsí & ÖZET \\
\hline $\begin{array}{l}\text { Anahtar Kelimeler: } \\
\text { Sanal Kaytarma } \\
\text { İş Performansı } \\
\text { İşe Bağlılık }\end{array}$ & $\begin{array}{l}\text { Amaç - Konya il merkezinde faaliyet göstermekte olan bir bilişim işletmesindeki çalışanların sanal } \\
\text { kaytarma davranışları̈ın işe bağlılık algıları ile iş performansları arasındaki etkileşimlerini Ego } \\
\text { Tükenmesi Teorisi ve Üretkenlik Karşıtı İş Davranış Teorisi kapsamında incelemektir. Araştırmanın } \\
\text { temel sorusu "Sanal kaytarma ve işe bağlllık, iş performansını ne yönde ve nasıl etkilemektedir" olarak } \\
\text { belirlenmiştir. }\end{array}$ \\
\hline $\begin{array}{l}\text { Gönderilme Tarihi } 22 \text { Ağustos } \\
2020 \\
\text { Revizyon Tarihi } 26 \text { Kasım } 2020 \\
\text { Kabul Tarihi } 12 \text { Aralık } 2020\end{array}$ & $\begin{array}{l}\text { Yöntem - Nicel araştırma yöntemine göre tasarlanan araştırmada, Örücü ve Yildiz (2014) tarafından } \\
\text { oluşturulan "Sanal Kaytarma Ölçeği", Schaufeli vd. (2002) tarafından geliştirilen, Eryılmaz ve Doğa } \\
\text { (2012) tarafından Türkçeye çevrilen "İşe Bağlllı Ölçeği" ile Sigler ve Pearson (2000) tarafından } \\
\text { oluşturulan, Göç (2008) tarafından Türkçeye uyarlanan "İş Performansı" ölçekleri kullanılmıştır. } \\
\text { Araştırma evrenini Konya'da bilişim alanında faaliyet gösteren bir işletmenin } 420 \text { çalışanı } \\
\text { oluşturmakta olup tam sayım yöntemiyle bu işletmedeki çalışanlardan } 383 \text { adet kullanılabilir soru } \\
\text { formu ile veriler elde edilmiştir. Elde edilen verilere, SPSS ve AMOS programları kullanılarak } \\
\text { doğrulayıcı faktör analizi, korelasyon analizi ve yapısal eşitlik modeli analizleri yapılmış ve çeşitli } \\
\text { bulgular elde edilmiştir. }\end{array}$ \\
\hline \multirow[t]{2}{*}{$\begin{array}{l}\text { Makale Kategorisi: } \\
\text { Araştırma Makalesi }\end{array}$} & $\begin{array}{l}\text { Bulgular - Araştırma bulgularına göre sanal kaytarmanın işe bağlılık üzerinde anlamlı ve negatif } \\
\text { yönde etkisi bulunurken, iş performansı üzerinde anlamlı bir etkisi bulunamamıştır. İşe bağllı̆ı̆ın } \\
\text { iş performansı üzerinde pozitif yönlü anlamlı bir etkisinin bulunduğu belirlenmiştir. Diğer yandan } \\
\text { sanal kaytarmanın iş performansına etkisinde işe bağlllık aracı rol oynamamaktadır. }\end{array}$ \\
\hline & $\begin{array}{l}\text { Tartışma - Literatür incelemesi sonucunda sanal kaytarmanın yıkıcı ve sapkın bir davranış türü } \\
\text { olduğu görülmektedir. Bu kapsamda sanal kaytarmanın iş performansı ve işe bağlllı̆ga negatif bir } \\
\text { etkisinin ve işe bağlllığın da iş performansına pozitif bir etkisinin olacağı yönünde hipotezler } \\
\text { kurgulanmıştır. Araştırma bulgularında çalışanların işe bağlllıklarının iş performanslarına pozitif } \\
\text { yönde etkisi belirlenmiştir. Ayrıca sanal kaytarmanın işe bağllık üzerinde negatif yönlü etkisinin } \\
\text { olması da araştırmada beklenen sonuçtur. Diğer yandan sanal kaytarmanın iş performansı üzerinde } \\
\text { etkisi bulunmamıştır. Buna ek olarak sanal kaytarma ve iş performansı ilişkisinde de işe bağlılığın } \\
\text { aracı etkisinin olmaması da araştırmada literatürle örtüşmeyen sonuçlar olarak görülmektedir. }\end{array}$ \\
\hline
\end{tabular}

\begin{tabular}{|c|c|}
\hline ARTICLE INFO & ABSTRACT \\
\hline Keywords: & $\begin{array}{l}\text { Purpose - This study aims to examine the interactions between the perception of work engagement } \\
\text { and work performance of employees' cyberloafing behavior in an IT industry in downtown Konya } \\
\text { within the ego-depletion theory framework. }\end{array}$ \\
\hline Work Engagement & $\begin{array}{l}\text { Design/methodology/approach - Quantitative research method has been applied in the research. In } \\
\text { the study, "Cyberloafing Scale" created by Örücü and Yildiz (2014), Schaufeli et al. (2002), "Work }\end{array}$ \\
\hline Information Sector & $\begin{array}{l}\text { Engagement Scale" which has been translated into Turkish by Eryılmaz and Doğa (2012), and "Job } \\
\text { Performance" scales created by Sigler and Pearson (2000) have been used. Data have been obtained }\end{array}$ \\
\hline Received 22 August 2020 & $\begin{array}{l}\text { from the sample through the questionnaire form. The universe of the research consists of } 420 \\
\text { employees of a firm operating in informatics in Konya. The sampling frame consists of the usable }\end{array}$ \\
\hline Revised 26 November 2020 & questionnaire received from 383 employees in this firm. Confirmation factor analysis, correlation \\
\hline Accepted 12 December 2020 & $\begin{array}{l}\text { analysis, and structural equation model analysis have been applied to the obtained data using SPSS } \\
\text { and AMOS programs, and various results have been obtained. }\end{array}$ \\
\hline Article Classification: & $\begin{array}{l}\text { Findings - According to the research findings, while cyberloafing has a significant and negative } \\
\text { effect on work engagement, there is no significant effect on job performance. It has been determined }\end{array}$ \\
\hline Research Article & \\
\hline
\end{tabular}

\section{Önerilen Atıf/Suggested Citation}

Erdem, A., T. (2020). Sanal Kaytarma Davranışının İş Performansına Etkisinde İşe Bağlılığın Aracı Rolüne Yönelik Bilişim Sektöründe Bir Araştırma, İ̧̧letme Araştırmaları Dergisi, 12 (4), 3843-3858. 
that work engagement has a significant positive effect on job performance. On the other hand, work engagement does not play a mediating role in the effect of cyberloafing on work performance.

Discussion - As a result of the literature review, it has been seen that cyberloafing is a destructive and deviant type of behavior. In this context, a hypothesis has been built that cyberloafing will have a negative effect on job performance and work engagement and that work engagement will have a positive effect on job performance. In the research findings, a positive effect of employees' work engagement on their job performance has been determined. Also, the expected result of the study is that cyberloafing has a negative effect on work engagement. On the other hand, cyberloafing does not affect job performance. Besides, the lack of a mediator effect of work engagement in the relationship between cyberloafing and work performance is considered a result of inconsistent results in the published literature.

\section{GİRiş}

Teknolojinin insan hayatını kolaylaştırdığı durumlar olmasına rağmen bazı durumlarda da olumsuz etkilerinin olduğu söylenebilir. Teknolojiyle birlikte internetin de gelişmesi gerek örgütlerin ve gerekse bireylerin eylemlerini hem çeşitlendirmekte hem de bu eylemleri kolaylıkla yerine getirmelerine yardımcı olmaktadır. Diğer yandan internetin yoğun olarak kullanılması örgüt yapılarının ve insan davranışlarının değişmesine sebep olurken özellikle örgütlerin olumsuz durumlarla karşılaşmalarına da neden olduğu görülür. Bu kapsamda internetin, işletmelerde üretim miktarlarını arttırarak kârlılığı yükselttiği görülürken hizmet işletmelerinde ise müşteri memnuniyetinin paylaşılmasında önemli rol oynadığı bilinir. TÜiK raporları, Türkiye'deki her 10 veya daha fazla çalışanı bulunan işletmelerin yaklaşı \% 93 'ünün internet bağlantısı kullanarak faaliyetlerini sürdürdüklerini belirtmektedir (TÜİK, 2018a). Yine TÜiK raporu sonucuna göre işletmeler çağa ayak uydurma açısından faaliyetlerini internet ortamında bilgisayar ve bilişim araçlarını kullanarak gerçekleştirmektedir. Buna ek olarak TÜiK (2018b)'in 2005 yılında yayınladığı rapor göz önüne alındığında; Türkiye'de bireylerin internet kullanım oranları 2005 yılında yaklaşık \%28'iken 2018 yılında yaklaşık \%91'e çıkmıştır. Bu iki rapor da göstermektedir ki gerek bireyler arasında ve gerekse işletmelerde internet kullanım oranları giderek yaygın hale gelmiştir. Bu durumun asıl sebebi ise çalışanların iş yerlerindeki bilgisayarlardan ve diğer bilişim araçlarından internete rahatlıkla ulaşabilmeleri olarak düşünülmektedir.

Günümüzde, ileri teknoloji ve kitle iletişim araçlarının kişilerin hayatlarını kolaylaştırmak adına kullanıldığı görülmektedir. Diğer yandan iş dünyasında da teknolojinin yoğun olarak kullanılması kaçınılmaz hale gelmiştir. Bu kapsamda iletişim ve teknoloji araçları işlemlerin hızlı bir biçimde yapılmasını sağlayarak bilgiye ulaşım hızını arttırmaktadır (Gezer ve Barutçu, 2020: 36). Teknoloji ve bilişim araçlarının sıklıkla kullanıldığı örgütler bu araçlardan fazlasıyla fayda sağlamalarına rağmen bazı durumlarda bu araçların olumsuz etkileri de görülebilir. Çalışanların mesai saatleri içerisinde internet erişimlerini kişisel amaçla kullanmaları hem örgüt kaynaklarının boşa kullanılmasına hem de çalışanların performanslarının düşmesine sebep olabilir. İnternet ve bilişim olanaklarının olumsuz yönde kullanılması ilgili literatürde sanal kaytarma olarak tanımlanmakla birlikte bu durumun iş performansı ve işe bağllığı azaltacağı düşünülmektedir. Bu kapsamda Amerika'da yapılan araştırmalarda yaklaşık 34 milyon işgören bir hafta içerisinde 200 milyon saat sanal kaytarma davranışı gösterdiği ve bu davranışın iş yerinde internet olanaklarını kişisel amaçla kullanmak suretiyle örgüt çalışanlarının performanslarını azaltıcı etkisinin olduğu belirlenmiştir (Blanchard ve Henle, 2008: 1068). Türkiye'de yapılan çalışmalarda, çalışanların iş yerinde sanal kaytarma kavramı kapsamında internet kullanım oranları \%33,8 olarak belirtilmektedir (Örücü ve Yildiz, 2014: 99). 2019 yılı TUIK raporlarına göre bu oran gözle görülür bir şekilde artmış ve Türkiye'de çalışanların mesai saatleri içerisinde internet kullanım amaçları incelenmiştir. Rapora göre çalışanların \%71,5'inin internette müzik dinlediği, \%81,4'nün sosyal medya üzerinde kişisel fotoğraf ve video paylaşımı ile mesaj alıp gönderme işlemleri yaptıkları, \%82,7'sinin sesli veya görüntülü konuşma yaptığı ve yaklaşık \%94'ünün mesajlaştığı belirlenmiştir (TUIK, 2019). Buna ek olarak 2019 yılında yapılan raporlamalara göre dünya genelinde, örgütlerde çalışanların yaklaşık \%60'ının işleriyle ilgisi olmayan internet kullanımı yaptıkları belirlenmiştir (Lim, 2020: 2). Türkiye'de ise M. Kurt (2011)'un öğrenciler üzerinde yaptığı araştırmaya göre araştırmaya katılan öğrencilerin yaklaşık \%39' unun ders saatleri içinde interneti müzik dosyası indirmek için kullandıkları belirlenmiştir.

Literatürde sanal kaytarma konusuna yönelik yapılan araştırmalarda genel olarak örgütleri olumsuz yönde etkilediğinden bahsedilerek sapkın bir davranış belirtilmektedir (Wu vd., 2020: 57). Sanal kaytarmanın örgütleri olumsuz yönde etkilemesi nedeniyle araştırma kapsamında bu davranışın işe bağlılık ve iş 


\section{A. T. Erdem 12/4 (2020) 3843-3858}

performansına etkileri üzerinde durulmaktadır. Araştırmanın temel sorunu; sanal kaytarma davranışında bulunan çalışanların örgüt işlerinden uzaklaşarak iş performanslarında düşme görülmesi ve bu noktada işe bağlllıklarının azalma ihtimaline yönelik olumsuz etkileridir. Bu bilgiler doğrultusunda araştırmanın amacl; sanal kaytarma, işe bağlllık ve iş performansı ilişkilerini ego tükenme teorisi ve üretkenlik karşıtı iş davranışı teorisi kapsamında analiz etmektir. Bu doğrultuda araştırmanın temel sorusu "Sanal kaytarma, işe bağhllık ve iş performansını ne yönde ve nasıl etkilemektedir" olarak belirlenmiştir. Araştırma çerçevesinden belirlenen araştırma sorusunu cevaplamak amacıyla Konya il merkezinde bilişim sektöründe faaliyet gösteren bir işletmenin çalışanlarına yönelik bir saha araştırması yapılmıştır.

Literatürde sanal kaytarma ile iş performansı (K. L. Askew, 2012; Fındıklı, 2016; Kuznek, 2019; Kuznek ve Güzel, 2019; Lim ve Chen, 2012; Mercado vd., 2017; Özüdoğru ve Yıldırım, 2020; Ugrin ve Pearson, 2013), sanal kaytarma ile örgüte bağlllık (Candan ve İnce, 2016; Güngör, 2016; Niaei vd., 2014; Rahayuningsih ve Putra, 2018; Runing S ve Cahyadin, 2012; Usman vd., 2019) ve iş performansı ile işe bağlılık arasında (Bayramoğlu vd., 2020; Carmeli ve Freund, 2003; Hunter ve Thatcher, 2007; İnce ve Özbozkurt, 2019; Loan, 2020; Supriyanto, 2013; Yavuzkılıç, 2020; Yorulmaz ve Karabacak, 2020) etkileşimi belirlemeye yönelik birçok çalışma yapılmış olmasına rağmen bu 3 konunun birlikte ele alındığı herhangi bir araştırmaya rastlanılmamıştır. Bu durumun araştırmanın özgün yönünü oluşturacağı ve ilgili literatüre katkı sağlayacağ1 düşünülmektedir.

\section{KAVRAMSAL ÇERÇEVE}

\subsection{Sanal Kaytarma}

Sanal kaytarma (cyberloafing) kavramı, Lim (2002)'in yapmış olduğu araştırma ile popülerlik kazanmaya başlamakla birlikte son yıllarda Türkçe literatürde da popüler ve geliştirilmeye açık bir kavram olarak görülmektedir (Kuzenk, 2019: 15). Sanal kaytarma örgüt ortamında başta internet olmak üzere örgütün çalışanlara sağladığı bilişim teknolojilerinin suiistimal edilmesidir. Diğer bir ifadeyle çalışanlara örgüt amaçları doğrultusunda kullanmalarına yönelik sağlanmış olan internet ağlarını, çalışanların mesai saatleri içerisinde kişisel e-postalarını kontrol etmek amacıyla ve örgütün işleriyle doğrudan ilgisi olmayan internet sayfalarına erişim sağlamak suretiyle kullanmak ve bu davranışı da gönüllü yapmak olarak tanımlanmaktadır (Kim, 2012: 38; Lim, 2002; Ugrin ve Pearson, 2013: 813; Vitak vd., 2011).

Her ne kadar sanal kaytarma davranışının örgütleri olumsuz yönde etkilediği belirtilse de bazı araştırmacılar sanal kaytarmanın örgüte olumlu etkilerinin olabileceğini de belirmektedir. Bu konuda iki farklı görüş öne sürülmektedir. Birinci görüşü savunan Cheng vd. (2020) sanal kaytarmayı çalışanların mesai saatlerini örgüt amaçları doğrultusunda değerlendirmeleri ve en verimli zamanlarını örgüt faaliyetlerinde harcamaları gerekirken kişisel amaçları doğrultusunda hareket etmeleri sonucunda verimsizliğe sebep olarak uygunsuz davranışlar sergilemeleri durumu olarak nitelendirmektedir. Vitak vd. (2011: 1751) sanal kaytarmayı çalışanların iş yerinden siber sapkınlık yapmaları olarak açıklamakla birlikte çalışanların interneti kişisel anlamda eğlence amaçlı kullanmaları olarak da ifade ederek bu davranışın örgüt performansını düşüren bir davranış türü olduğunu belirtmektedir. Sanal kaytarmanın olumsuz olduğunu savunan diğer yazarlardan olan Liberman vd. (2011: 2192)'e göre ise çalışanların sanal kaytarma davranışını kendi menfaatlerine göre yapmaları sonucunda bireysel verimlilik azalmakta ve bu durum örgütün verimliliğine de olumsuz olarak zarar vermektedir. Ayrıca örgüt bu davranış sonucunda maddi kayıplar yaşayarak, internet aksaklıkları oluşmakta ve yasal yaptırımların uygulanması nedenleriyle zamanın verimsiz kullanılmasına da neden olmaktadır. Sanal kaytarmaya bakış yönünden diğer bir görüş ise bu davranış türünün örgüte ve kişiye olumlu katkılarının olmasıdır. Blanchard ve Henle (2008: 1069)'ye göre sanal kaytarma, çalışanların yaratıcılık düzeylerini arttırmalarına katkı sağlayarak onların daha esnek, öğrenme odaklı, uyumlu ve işbirliğine yatkın yetenekler kazanmalarını sağladığı için zararlı olmadığını savunmaktadır.

Literatürde sanal kaytarmayla ilgili birçok araştırma bulunmaktadır. Bu araştırmaların genel olarak demografik faktörlerden cinsiyet faktörü ile ilişkilendirilen çalışmaların olduğu görülmektedir. Hollinger vd. (1992) yaptıkları araştırmada sanal kaytarmayı çalışma süresiyle ilişkilendirmiş, çalışma süresinin artmasıyla sanal kaytarmanın azaldığını belirlemiştir. Vitak vd. (2011) sanal kaytarmanın oluşma nedenlerine yönelik araştırmalarında demografik faktörleri kontrol değişkeni olarak ele alarak sanal kaytarmanın demografik özellikleriyle ilişkili olduğunu belirlemiştir. Özkalp vd. (2012) yaptıkları araştırmada özel ve kamu sektör 


\section{A. T. Erdem 12/4 (2020) 3843-3858}

çalışanlarını karşılaştırarak özel sektörde çalışan personellerin kamu sektörüne göre sanal kaytarma davranışını daha az sergilediklerini belirlemişlerdir. Liberman vd. (2011: 2193) demografik faktörlere göre sanal kaytarmayı inceleyerek kadınların erkeklere göre daha az sanal kaytarma davranışı gösterdiklerini belirlemiştir.

\section{2. İşe Bă̆lılık}

Örgütlerin başarılarında en önemli ve taklit edilemez unsurların başında insan faktörü gelmektedir. Örgütlerin rakiplerine karşı rekabet avantajı elde edebilmeleri ve verimli bir şekilde faaliyetlerini sürdürebilmeleri için çalışanlarının başarılı olması gerekmektedir. Çalışanların daha verimli, iyi performansla ve yüksek motivasyonla çalışmalarında işe bağlllıkları ile işlerinden tatmin olmaları önemlidir (Freudenberger, 1974; Tutar, 2000). Baysal ve Paksoy (1999)'a göre işe bağllık, çalışanların faaliyet gösterdikleri örgütlerde, örgütün benimsediği amaç ve kuralları benimseyerek, kendilerinden beklenenden daha fazla çaba sarf etmeleriyle buna istekli olmaları durumudur.

İşe bağlılık kavramı ilk olarak Kahn (1990) tarafından ortaya atılmıştır. İşe bağlılık, çalışanların işlerini yaptıkları sırada kendilerini duygusal ve fiziksel olarak işlerine vermeleridir (Kahn, 1990: 694). Diğer bir tanıma göre işe bağlllık çalışanların örgüt amaçları doğrultusunda işleriyle ilgili faaliyetleri etkili ve verimli bir şekilde yerine getirme kabiliyetleri olarak tanımlanmaktadır (Schaufeli vd., 2002). Literatürde işe bağlllık genel olarak tükenmişlik ile ilişkilendirilmektedir. Çalışanların tükenmişlik yaşamaları örgütleri de olumsuz yönde etkilemekle birlikte çalışanların tükenmesi yerine işlerine bağlllık duyguları hissetmeleri, bu kişileri işlerine karşı daha enerjik ve verimli yapacak ve çalışanlar işlerini yaparlarken kendilerini iyi hissedeceklerdir (Schaufeli vd., 2008: 176). Buna ek olarak işe bağlllıkları yüksek olan bireylerin enerjilerinin yüksek olması sebebiyle çalışma konusunda diğer çalışanlara göre daha istekli ve iş yapmaya daha yatkın oldukları belirtilmektedir (Bakker ve Albrecht, 2018: 4-5). Starnes ve Truhon (2006: 3) işe bağlılığ1 çalışan davranışlarıyla, inanç ve tutumların ölçülmesi ve değişken duygusal bir tepki oluşturma süreci olarak tanımlamaktadır. Buna ek olarak işe bağlılık duygusu yüksek olan çalışanların çalıştıkları örgütte kalma istekleri yüksek olmakla birlikte buna bağlı olarak performansları da yüksek olacaktır (Liu, 2019: 2). Akdeniz (2018: 22), işlerine bağlı olan çalışanların faaliyet gösterdikleri işleriyle ilgili olarak aktif bir bağ geliştirdiklerini ve bu kişilerin yüksek performans eğiliminde olduklarını belirtmektedir. Bu noktada işe bağll1ık hisseden bireylerin örgüte karşı daha verimli ve etkin çalışmaları durumunda örgütte çalışanlar arasında olumlu bir rekabet havasının da oluşacağı düşünülmektedir.

Literatürde yapılan araştırmalara göre işe bağlılığı yüksek olan bireylerin psikolojik sermaye algılarının da yüksek olduğu görülmekle birlikte bu bireylerin örgütte daha iyi performans sağlayan, kendi kaynaklarını oluşturan mutlu bireyler oldukları görülmektedir (Bakker vd., 2011: 5). Kanten (2012)'e göre çalışanların işe bağlılık algılarının yüksek olması bu kişilerin performanslarını arttırmakta ve örgüte katkılarının yüksek olduğunu belirtmektedir. Sonuç olarak işe bağlılıkları yüksek olan işgörenlerin motivasyonları yüksek olmakla birlikte iş doyumları ve iş performansları da yüksek olmaktadır (Roberts ve Davenport, 2002: 21).

\section{3. İş Performansı}

Performans, çalışanların örgütte yapmaları gerekli olan görevler ile şahsen yaptıkları faaliyetler arasındaki ilişki olarak nitelendirilmektedir (Bayram, 2006: 47). Diğer bir ifadeyle performans, kişi veya örgütlerin bir işe yönelik tanımlanmış özellikleri ile yetenekleri sonucunda elde edilen çıktı olarak belirtilmektedir (Erdoğan, 1991: 154). İş performansı, çalışanların örgütün amaçları doğrultusunda çabalayarak hedefe ulaşmak için göstermiş oldukları davranışların bütünü olarak ifade edilmektedir (Williams ve Anderson, 1991: 602). Syamsir (2020)'e göre iş performansı, bir işin yapılabilmesi amacıyla harekete geçme, çaba harcama ve iş faaliyetini gerçekleştirebilmek için harcanan zamanın elde edilen sayısal faydası olarak belirtilmektedir.

Örgütsel performansın arttırılması amacıyla örgütsel iç süreçlerin geliştirilmesi gerekmektedir. Örgütlerin iç süreçleri de insan performansının artırılmasıyla gerçekleşmektedir (Bekmezci vd., 2020: 1588; Serinikli, 2020). $\mathrm{Bu}$ kapsamda çalışanların performanslarının artmasıyla motivasyonları da artacak bu durum örgütlerde verimliliği sağlayacaktır. Diğer yandan bireysel performans, çalışanların hedeflerine ulaşılmaları noktasında örgütün çalışanlardan beklentilerini yerine getirme amaçlı üst seviyede çaba gösterme ve yapılan bu faaliyetlerden örgüt çıkarına elde edilen çıtıların paralel olmasıdır (Özkan ve Omay, 2019). 


\section{A. T. Erdem 12/4 (2020) 3843-3858}

Örgütlerin ve işletmelerin hedef ve başarılarına ulaşma düzeyleri, çalışanların örgütte gösterdikleri performansla doğrudan ilgilidir. Performans çok değişkenli bir kavram olmakla birlikte işletmelerin başarıları ve süreklilikleri performans değerleriyle ölçülmektedir. Performans kavramı, örgütlerin stratejik planlarını daha akılcı ve ekonomik bir biçimde gerçekleştirir (Bayar, 2020: 1987). İşletmelerin, hedeflerine ulaşabilmeleri için en önemli kaynakları olan insan unsurunun verimliliğini arttıracak önlemleri almaları gerekmektedir (Polat ve Dilek, 2020: 1280). Örgütlerin sahip oldukları insan gücü bu kurumların sahip oldukları entelektüel sermayelerini gösterdiği düşüncesinden yola çıkılarak güçlü bir entelektüel sermayeye sahip örgütlerin faaliyetlerini daha planlı yaparak örgütsel performanslarını rakiplerine göre arttıracağı düşünülmektedir.

\subsection{Sanal Kaytarma, İşe Bağlılık ve İş Performansı İlişkileri}

Sanal kaytarmaya en fazla dayanak gösterilen teorinin ego tükenmesi teorisi olduğu belirtilmektedir (K. Askew vd., 2014: 510). Ego tükenmesi teorisine göre çalışanların, irade güçlerini fazlasıyla kullanmaları nedeniyle bu güç zamanla zayıflamaktadır. Özüdoğru ve Yıldırım (2020: 469) irade gücünü kas gücüne benzeterek, bu gücün kullanıldıkça azalacağını, fakat dinlenince tekrar iyileşeceğini belirtmektedir. K. Askew vd. (2014:510), ego tükenmesiyle sanal kaytarmanın ilişkisini "örgütte çalışanların irade güçleri tükendiği anda bu kişilerin irade güçlerini tekrar kazanabilmeleri için işleri dışındaki faaliyetlere yöneleceklerdir." Şeklinde açıklamaktadır. Bu noktada çalışanlar sanal kaytarma davranışı göstermektedirler. Ego tükenmesi teorisinde çalışanlar işlerinden sıkıldıklarında ve yorulduklarında yenilenmek ve diğer bir ifadeyle mesleklerinden anlık uzaklaşmak adına sanal kaytarma yapabilmektedirler (Inzlicht ve Schmeichel, 2012; Wagner vd., 2012: 453; Wu vd., 2020: 58).

Sanal kaytarma üretkenlik karşıtı iş davranış teorisiyle de açıklanmaktadır (Özüdoğru ve Yıldırım, 2020: 469). Üretkenlik karşıtı iş davranış teorisinin alt boyutu olan "geri çekilme" boyutu sanal kaytarma davranışı ile ilişkilendirilmektedir. Teorinin geri çekilme boyutuna göre; çalışanlar işlerine kendilerinden beklenen süreden daha az zaman ayırarak çalışmaları gereken zamanda sanal kaytarma davranışı sergileyebilmektedirler (Spector vd., 2006: 450). Diğer yandan çalışanlar iş performanslarından olumsuz yönde saparak örgüt işleyişini aksatabilmektedirler. Bu durum örgütlerin hedeflerinden sapmalarına neden olabilmektedir. Buna ek olarak örgütün değer ve normlarına uymayarak ters düşen çalışanlar planlı ve bilinçli bir biçimde bu davranışları sergileyebilmektedirler (Polatçı vd., 2014: 3-4). Bu kapsamda sanal kaytarma davranışı örgütleri olumsuz etkileyerek çalışanlarda performans düşüklügüne neden olabilmekte ve çalışanların işlerine bağlllıklarını azaltabilmektedir.

Sanal kaytarma örgütler açısından genelde olumsuz bir durum olarak görülmekle birlikte bazı durumlarda kazanım olarak görülerek verimlilik ve performansı arttırdığı belirtilmektedir (Lim ve Chen, 2012). Sanal kaytarmanın olumlu veya olumsuz etkileri örgütün yapısı, çalışanların özellikleri, iş tanımları, izin verilen bireysel internet kullanım süreleri, örgüt iklimi ve kültürü gibi durumlara bağlı olarak değişmektedir (Blanchard ve Henle, 2008; Blau vd., 2006; Lim ve Chen, 2012; Örücü ve Yıldız, 2014; Palladan, 2018).

İşe bağlılığın sanal kaytarmaya etkisine yönelik araştırmaların oldukça kısıtlı olduğu görülmektedir. Bu iki değişken arasındaki etkileşime yönelik tek araştırma olan Rahayuningsih ve Putra (2018) tarafından yapılan araştırmada işe bağlılıklarının sanal kaytarma davranışını negatif yönde etkilediği belirtilmektedir. Garrett ve Danziger (2008: 942) yaptıkları araştırmada, işlerine yönelik duygusal bağı yüksek olan çalışanların örgüt amacı dışında internet kullanma davranışını yanlış bir davranış türü olarak nitelendirdiklerini belirlemiştir. İşlerine bağlı çalışanların işle ilgisiz eylemlerden kaçınma eğiliminde olduklarını ve bu gibi faaliyetlerin verimliliği azaltarak performansı düşürdüğünü belirlemişlerdir.

İşe bağlllık ile iş performansı arasında pozitif yönlü bir ilişkinin varlığından bahseden çalışmalar (Brett vd., 1995; Mowday vd., 1974; Ward ve Davis, 1995; Yousef, 2000; Ampofo, 2020) olmakla birlikte bazı çalışmalar (Wright, 1997) bu ilişkinin negatif yönlü olduğunu belirtmektedir. Randall (1987) çalışanlarda görülen yüksek bağlılık düzeyinin örgüte yüksek düzeyde iş performansı olarak döneceğini belirtmektedir. Meyer vd. (1989) çalışanların işe bağlılığı ile iş performansı arasında pozitif yönlü bir ilişki olduğu sonucuna ulaşmışlardır. Rose vd. (2009)'nin Malezya'da yapmış oldukları araştırmaya göre işlerine bağlı bireylerin iş performanslarının arttığını belirlemişlerdir. Kass vd. (2001) yaptıkları araştırmada iş sıkıntısının işe bağlılığı azalttığını ve bu nedenle de çalışanların işlerine devamsızlık eğilimi göstererek örgütte performans düşüklüğünün olduğunu belirlemişlerdir. Ampofo (2020) yaptığı araştırmada işlerine bağlllık duygusu yüksek çalışanların daha fazla performans gösterdiklerini belirlemiştir. 
Sanal kaytarmanın iş performansını negatif yönde etkilediği araştırmaların (K. Askew, 2012; Blau vd., 2006; Genç, ve Aydoğan, 2015; Henle ve Kedharnath, 2012; Kaplan ve Öğüt, 2012; Omolade vd., 2018; Palladan, 2018; Sevinç vd., 2012; Wu vd., 2018) olduğu görülmektedir. Bu araştırmalarda sanal kaytarmanın verimlilik ve kişisel performansı azaltması nedeniyle örgüte zarar verdiği belirtilmektedir. Saghih ve Nosrati (2020'nin İran devlet üniversitesinden yaptıkları araştırmada çalışanların sanal kaytarma davranışında bulunmasının iş performansını negatif yönde etkilediğini belirlemişlerdir.

\section{YÖNTEM}

\subsection{Araştırmanin Evreni ve Örneklem Çerçevesi}

Araştırmanın evrenini Konya'da bilişim alanında faaliyet gösteren bir işletmede görev yapmakta olan 420 çalışanı oluşturmakta olup tam sayım yöntemiyle bu işletmedeki çalışanlardan 383 adet kullanılabilir soru formu ile veriler elde edilmiştir. Soru formlarının geri dönüş oranının yaklaşık \%91 olması araştırmanın bilimsel yeterliliği (Lewin vd., 1995) sağladığını göstermektedir. Araştırma verileri 01.11.2019 - 03.12.2019 tarihleri arasında ilgili bilişim firması çalışanlarından elde edilmiştir.

Araştırmada bilişim sektörüne yönelik bir işletmenin seçilmesinin temel sebebi, bilişim işletmelerinde yoğun olarak bilgi işlem araçlarının kullanılması nedeniyle bu işletmelerde sanal kaytarma davranışının diğer işletmelere göre daha yoğun olacağı ve bu işletmeleri diğer işletmelere göre daha fazla olumsuz etkileyeceği düşüncesidir.

\subsection{Araştırmanın Modeli ve Hipotezler}

Araştırma kapsamında sanal kaytarma, işe bağlllık ve iş performansına ilişkin araştırma modeli Şekil 1'de gösterilmektedir.

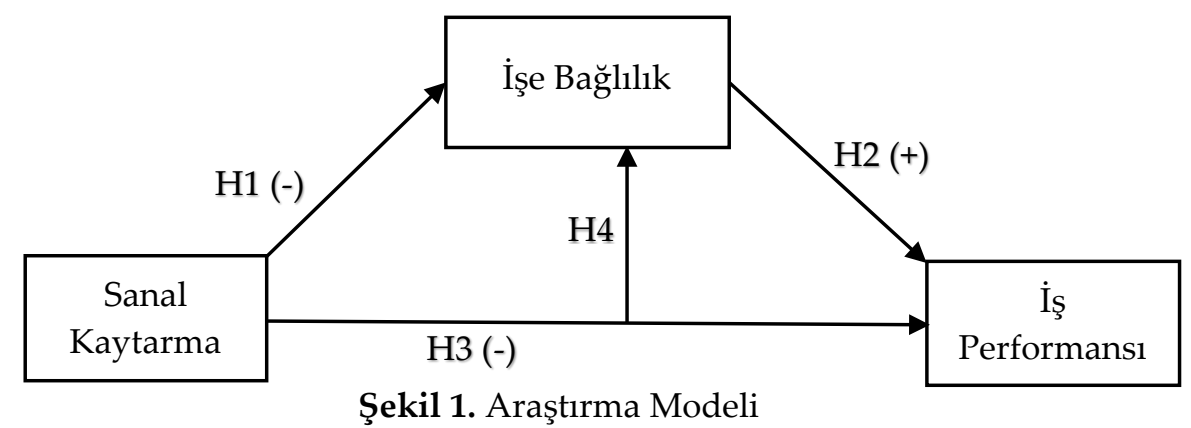

Şekil 1'deki araştırma modeli sanal kaytarma (bağımsız değişken), işe bağlılık (aracı değişken) ve iş performansı (bağımlı değişken) olarak kurgulanmıştır. Araştırma modeli doğrultusunda aşağıdaki hipotezler geliştirilmiştir;

Hipotez 1: İşe bağlılığın sanal kaytarma üzerinde negatif yönlü anlamlı bir etkisi vardır.

Hipotez 2: İşe bağlılı̆̆ın iş performansı üzerinde pozitif yönlü anlamlı bir etkisi vardır.

Hipotez 3: Sanal kaytarmanın iş performansı üzerinde negatif yönlü anlamlı bir etkisi vardır.

Hipotez 4: Sanal kaytarma ile iş performansı arasındaki ilişkide işe bağlılığın aracı etkisi vardır.

\subsection{Araştırmada Kullanılan Ölçekler ile Güvenilirlik ve Geçerlilik Analiz Sonuçları}

Araştırmada kullanılan soru formu, araştırma ölçeklerinden oluşturulmuştur. Bu kapsamda Örücü ve Yildiz (2014) tarafından oluşturulan 14 ifadeden oluşan "Sanal Kaytarma Ölçeği” kullanılmıştır. Araştırmanın diğer değişkenleri olan ve Schaufeli vd. (2002) tarafından geliştirilip Eryılmaz ve Doğa (2012) tarafından Türkçe' ye uyarlanan kısa form halindeki 9 maddelik "İşe Bağlllık Ölçeği" ile Sigler ve Pearson (2000) tarafından oluşturulan ve Çöl (2011) tarafından Türkçeye uyarlanan 4 ifadelik "İş Performansı" ölçeği kullanılmıştır.

Araştırmada uygulanan ölçeklerin güvenilirliklerini test etmek için Cronbach Alfa testinden yararlanılmıştır. Alfa katsayıları; sanal kaytarma ölçeği için $\alpha=0.947$, işe bağlllık ölçeği $\alpha=0.925$ ve iş performansı ölçeği $\alpha=$ 0.898 olarak belirlenmiştir. Bu sonuçlara göre ölçeklerin güvenilir olduğu söylenebilir. Araştırma kapsamında yapılan temel bileşen analizine göre, tek faktörlü araştırma yapısının geçerliliğini sınamak amacıyla AMOS programı kullanılarak doğrulayıcı faktör analizi (DFA) uygulanmıştır. İyi uyum ve geçerlilik ölçüleri ile araştırma modeli Tablo 1'de gösterilmektedir. 
Tablo 1. Model-Veri Uyum Değerleri

\begin{tabular}{ll}
\hline Veri-model uyum indisleri & Kabul edilebilir uyum değerleri \\
\hline Ki-Kare $(\mathrm{X} 2)=380,40$ & $\mathrm{SD}=252$, p<0,01 \\
GFI $=0.910$ & Değeri l' e yaklaştıkça iyi bir model göstergesidir (Tanaka ve Huba, 1985) \\
NFI $=0.950$ & Değeri l' e yaklaştıkça iyi bir model göstergesidir (Bentler ve Bonett, 1980) \\
CFI $=0.976$ & Değeri l' e yaklaştıkça iyi bir model göstergesidir (McDonald ve Marsh, \\
& $1990)$ \\
TLI $=0.970$ & Değeri l' e yaklaştıkça iyi bir model göstergesidir (Bentler ve Bonett, 1980) \\
RMSEA = 0.50 & Değeri 0.08 altında iyi bir model göstergesidir (Browne ve Cudeck, 1993) \\
CMIN/SD = 1.51 & Değeri 1 ve 5 arası olmalı (Marsh ve Hocevar, 1985) \\
\hline Not: $\chi 2$, Ki-Kare; SD, Serbestlik Derecesi, GFI = İyilik Uyum İndeksleri, NFI = Normalleştirilmiş Uyum İndeksi, \\
CFI = Karşılaştırmalı Uyum İndeksi, TLI, Tucker-Lewis indeksi; RMSEA = Yaklaşık Hataların Ortalama Karekökü, \\
X2/SD, Relative Ki-Kare.
\end{tabular}

Bu analize göre araştırmada elde edilen verilere 3 farklı ölçme modele göre test edilmiş, uyum indisleri X2/SD, RMSEA, GFI, TLI, CFI ve NFI değerli ile elde edilen sonuçlar ile iyi uyum ve geçerlilik ölçüleri Tablo 1'de gösterilmektedir. Tablo 1'de görülen 3 faktörlü modele yönelik $\chi 2$ değerinin anlamlı olduğu görülmektedir. Bunula birlikte, $\chi 2 / S D$ değerinin $(1,51)$ 5'in altında olması nedeniyle model geçerlilik açısından uyum ölçütünü sağlamaktadır. Bunun yanı sıra GFI $=0.910, \mathrm{CFI}=0.976, \mathrm{NFI}=0.950$ ve RMSEA $=0.50$ göstergeleri açısından da verilerin uyumlu olduğu görülmektedir (Tablo 1). Tek faktörlü model ile çok faktörlü model arasında karşılaştırmalı uyum tablosu Tablo 2'te belirtilmektedir.

Tablo 2. Karşılaştırmalı model uyumu

\begin{tabular}{|c|c|c|c|}
\hline Modeller & $\mathrm{X}^{2}$ & SD & $\Delta X^{2}$ \\
\hline Tek Faktörlü Model & 5210.10 & 225 & - \\
\hline $\begin{array}{l}3 \text { Faktörlü Model } \\
\text { Sanal Kaytarma, İse Bağlılık, İs Performansı }\end{array}$ & 380.40 & 252 & 4829.70 \\
\hline
\end{tabular}

Araştırma kapsamında verilerin analizine göre tek faktörlü model ile çok faktörlü model arasındaki uyumu belirlemek amacıyla $\chi 2$ değerlerine "Ki-Kare Fark Testi" uygulanmış ve anlamlı bir farkın olduğu görülmüştür. (Tablo 3'de). Bu sonuca göre 3 faktörlü model verileri daha iyi uyumlu olduğunu göstermektedir. Çalışmaya 3 faktörlü (ilişkili) model ile devam edilmiştir. Analizler kapsamında sanal kaytarma ölçeğine yönelik sorularda faktör yükleri düşük olan 8, 9, 10 ve 13. sorunlar analiz kapsamından çıkarılmıştır.

Araştırma kapsamında ele alınan ölçeklerim ölçülmesi ile değişkenlerin derecelerini değerlendirmek amacıyla yakınsama ve ıraksama ayırt edici geçerlilik analizleri yapılmıştır. Ele alınan bir modelin geçerliliğine yönelik yapının oluşturulduğu bütün değişkenlerin aralarındaki yüksek korelasyon görülen ilişki gösteren yakınsama (convergent validity) ile modelin değişkenlerinin diğer değişkenlerle düşük korelasyon ilişkisini gösteren ıraksama ayırıcı (discriminant validity) geçerliliğini sağlaması gerekmektedir (Akdeniz, 2018: 41; Churchill Jr, 1979). Araştırma verilerine göre kullanılan araçların modeli ölçmesi yönünden yakınsama ve ıraksama ayırt edici geçerlilikleri incelenmiştir (Tablo 3).

Tablo 3. Değişkenlere Ait Ortalama, Standart Sapma, Güvenirlilik ve Korelasyon Değerleri

\begin{tabular}{|c|c|c|c|c|c|c|c|c|}
\hline & Ort & S.S & $\alpha$ & $\mathrm{CR}(\mathrm{t})$ & AVE & 1 & 2 & 3 \\
\hline 1. Sanal Kaytarma & 2.57 & .878 & .947 & .925 & .582 & - & & \\
\hline 2. İşe Bağlılık & 3.90 & .862 & .911 & .910 & .670 & .017 & - & \\
\hline 3. İş Performansı & 3.96 & .887 & .925 & .942 & .623 & $-.274^{* *}$ & $.505^{* *}$ & - \\
\hline
\end{tabular}

Not: SH, standart hata; ${ }^{*} 0,05^{* *} 0,01{ }^{* * *} 0,001$ düzeyinde anlamlıdır (çift-yönlü)

Tablo 3'te ilgili ölçekten elde edilen veriler için, AVE diğer bir ifadeyle OAV (ortalama açılanan varyans) değerlerine göre yakınsama geçerliliği belirlenmektedir. Yakınsama geçerliliği, araştırma yapısını ölçen boyut yapısının parçası olarak sayılabilmesi için kendi arasından belirli düzeyde korelasyonun bulunması gerekir (Bülbül ve Demirer, 2008). Diğer yansan modelin AVE değerinin 0,5 değerinden yüksek olması ilgili 


\section{A. T. Erdem 12/4 (2020) 3843-3858}

maddelerin örtük değişkenlerinin geçerli olduğunu göstermektedir. Tablo 4'te görüleceği üzere AVE değerlerinin 0,5'ten yüksek olması ile yakınsama geçerliliği sağlanmaktadır (Fornell ve Larcker, 1981; Hu ve Bentler, 1999). Ayırt edici geçerlilik için değişkenler arası korelasyonun 0.80 'den küçük olması ıraksama, ayırt edici geçerliliğin sağlandığını gösterir (Abubakar ve Ilkan, 2016; Erdem ve Karadal, 2020: 421; Kline, 2014). Tablo 5'te görüleceği üzere korelasyon değerlerinin $0,80^{\prime}$ den düşük olması ve anlamlı bir ilişkinin olduğunun görülmesi nedeniyle ıraksama ayırt edici geçerliliği sağlanmıştır.

\section{ARAŞTIRMA BULGULARI}

\subsection{Demografik Bulgular}

Araştırmadaki katılımcıların cinsiyet, kıdem, yaş ve eğitim düzeyi gibi demografik bilgileri, Tablo $4^{\prime}$ te açıklanmaktadır.

Tablo 4. Demografik Bulgular

\begin{tabular}{lrrlrr}
\hline Cinsiyet & F (Sıklık) & \% Yüzde & Mesleki Kıdem & F (Sıklık) & \% Yüzde \\
\hline Kadın & 185 & 48,3 & $1-10$ Yıl & 123 & 32,1 \\
Erkek & 198 & 51,7 & $11-20$ Yıl & 147 & 38,4 \\
& & & $21-30$ Yıl & 62 & 16,2 \\
& & & $31-$ üstü & 51 & 13,3 \\
Toplam & 383 & 100,0 & Toplam & 383 & 100,0 \\
\hline Yaş & F (Sıklı) & \% Yüzde & Eğitim Düzeyi & F (Sıklık) & \% Yüzde \\
\hline $18-25$ & 27 & 7,2 & Ilköğretim & 37 & 9,6 \\
$26-35$ & 143 & 37,3 & Lise\&Dengi & 91 & 23,8 \\
$36-45$ & 112 & 29,1 & Lisans & 186 & 48,5 \\
$46-55$ & 85 & 22,1 & Lisansüstü & 69 & 18,1 \\
56 ve üzeri & 16 & 1,3 & & & \\
Toplam & 383 & 100,0 & Toplam & 383 & 100,0 \\
\hline
\end{tabular}

Tablo 4'e göre katılımcıların \%48,3'ü kadınlardan, \%51,7'si erkeklerden oluşmaktadır. Mesleki kıdem değişkenlerine göre katılımcıların \%38,4'ünün 11 ile 20 yıl arası kıdeme sahip oldukları belirlenmiş ve katılımcıların genelde bu aralıkta oldukları görülmüştür. Katılımcıların diğer mesleki kıdem oranları ise yıllar itibariyle 1-10 yıl arası \%32,1, 21-30 yıl arası \%16,2 ve son olarak 31 yıl ve üzeri \%13,3 olarak belirlenmiştir. Katılımcıların yaş aralıklarına göre \%37,3'ünün, 26-35 yaş aralığında yoğunlaştığı görülmektedir. Diğer yaş oranları ise $\% 29,1^{\prime}$ i $36-45$ yaş, $\% 22,1^{\prime}$ i $46-55$ yaş arası, $\% 7,2^{\prime}$ si $18-25$ yaş ve 56 yaş üzeri ise $\% 4,3^{\prime}$ tür. Son olarak eğitim düzeylerine göre dağılım incelendiğinde katılımcıların \%9,6'sı ilköğretim, \%23,8'i lise ve dengi, \%48,5'i lisans ve \%18,1'i ise lisansüstü derecesine sahip personellerden oluşmaktadır. Katılımcıların yoğunlukla lisans mezunu oldukları belirlenmiştir.

\subsection{Araştırma Hipotezlerinin Test Edilmesi}

Araştırma değişkenlerine yönelik öncelikle Pearson Korelasyon yöntemi uygulan arak değişkenler arasındaki korelasyona bakılmıştır. Tablo 5'te değişkenler arası korelasyon değerleri görülmektedir.

Tablo 5. Değişkenlere ilişkin korelasyon değerleri

\begin{tabular}{lcccc}
\hline Değişkenler & Ort & 1 & 2 & 3 \\
\hline 1. Sanal Kaytarma & 2.57 & - & & \\
2. İşe Bağlllık & 3.90 & .017 & - & \\
3. İş Performansı & 3.96 & $-.274^{* *}$ & $.505^{* *}$ & - \\
\hline
\end{tabular}

Not: SH, standart hata; ${ }^{*} 0,05$ düzeyinde anlamlıdır (çift-yönlü). ${ }^{* *} 0,01$ düzeyinde anlamlıdır (çift-yönlü)

Tablo 5'e göre sanal kaytarma ile iş performansı arasındaki negatif yönde anlamlı bir ilişki gözlemlenmiştir $(\mathrm{r}=-.274, \mathrm{p}<0.01)$. İş performansı ile işe bağlılık arasındaki ilişkinin anlamlı ve pozitif yönde olduğu gözlemlenmiştir $(\mathrm{r}=.505, \mathrm{p}<0.01)$. Son olarak sanal kaytarma ile işe bağlllık arasındaki korelasyon değerleri incelendiğinde aralarında ilişki olmadığı söylenebilir $(\mathrm{r}=.017, \mathrm{p}>0.01)$. Tablo 6 'da sanal kaytarma, işe bağlılık ve iş performanslarına ilişkin etkiler görülmektedir. 
Tablo 6. Doğrudan etki

\begin{tabular}{|c|c|c|c|c|}
\hline Değişkenler & $\beta$ & $t$ değer & $\mathrm{SH}$ & $\mathrm{p}$ \\
\hline H1: İşe Bağlllık - Sanal Kaytarma & .074 & 1.345 & .056 & .179 \\
\hline H2: İş Performansı - İşe Bağlllık & .507 & 10.626 & .047 & $* * *$ \\
\hline H3: Sanal Kaytarma - İş Performansı & -.031 & -1.643 & .052 & $* * *$ \\
\hline
\end{tabular}

Tablo 6'ya göre işe bağlılığın sanal kaytarma üzerinde anlamlı bir etkisinin bulunmadı̆̆ belirlenmiştir ( $\beta=.074$, $\mathrm{t}=1.345, \mathrm{p}=0.179>0.01)$. H1 hipotezi desteklenmemektedir. İşe bağlılığın iş performansı üzerinde pozitif yönlü anlamlı bir etkisinin olduğu ortaya çıkmıştır $(\beta=.507, t=10.626, p<0.01)$. Bu duruma göre işe bağlılık çalışanlarda iş performansını da olumlu yönde etkilemektedir. Dolayısıyla H2 hipotezi desteklenmektedir. Son olarak sanal kaytarmanın iş performansını negatif yönde etkilediği görülmektedir $(\beta=-.031, t=-1.643, p<0.01)$. Dolayısıyla H3 hipotezi desteklenmektedir.

Araştırma kapsamında sanal kaytarma ile iş performansı arasındaki ilişkide işe bağlılı̆̆ın aracı etkisi incelenmektedir. MacKinnon vd. (2007: 594)'a göre aracı değişken, iki değişken arasında bulunan neden sonuç ilişkisini belirlemek amacı ile kullanılan analiz yöntemidir. Araştırmada aracılık etkinin ölçülmesi için; 1) Bağımsız değişkenin aracı değişkene etkisinin bulunması gerekmektedir. 2) Bağımsız değişkenin bağımlı değişken üzerinde etkisinin olması gerekmektedir. 3) Aracı değişkenin bağımlı değişken üzerinde etkisi olmalıdır, şartlarını sağlaması gerekmektedir (Baron ve Kenny, 1986). Araştırmada değişkenler arası aracı etkiyi belirlemek için araştırma verilerine Yapısal Eşitlik Modeli uygulanmıştır. Tablo 7'de aracı etki değerlerine ilişkin yapısal eşitlik modeli sonuçları belirtilmektedir.

Tablo 7. Aracı Etki Sonuçları

\begin{tabular}{lcccc}
\hline Değişkenler & Toplam Etki & Doğrudan Etki & Aracı Etki & $\mathrm{p}$ \\
\hline İşe Bağlılık - Sanal Kaytarma & .074 & .074 & - & \\
Sanal Kaytarma - İş̧ Performansı & .007 & -.031 & -.024 & .186 \\
İş Performansı - İşe Bağlılık & .507 & .507 & - & \\
\hline
\end{tabular}

Not: SH, standart hata; ${ }^{* * *} 0,01$ düzeyinde anlamlıdır (çift-yönlü)

Tablo $7^{\prime}$ de sanal kaytarma ile iş performansı arasındaki ilişkide işe bağlılığın aracı etkisinin olmadığı görülmektedir ( $\mathrm{p}=186>0,01)$. H4 hipotezi desteklenmemektedir.

\section{SONUÇ ve TARTIŞMA}

Sanal kaytarmanın, örgütteki çalışanların iş saatleri içerisinde örgüte ait bilişim araçları ile interneti kendi kişisel amaçları doğrultusunda kullanmaları olarak ifade edilmesine rağmen, günümüzde çalışanların bu eylemi kendi kişisel bilişim araçları olan cep telefonları, tablet veya dizüstü bilgisayarlarıyla da gerçekleştirdikleri bilinir. Bu kapsamda mesai zamanını da kişisel amaçla kullanması çalışanın sanal kaytarma yaptığını gösterdiği düşünülmektedir. Sanal kaytarmanın yapılmasıyla çalışanlar örgüt amaçlarından uzaklaşarak farklı işlere yönelecekler ve bu durumda çalışanlarda iş performanslarının azalacağı açıktır. Diğer yandan iş performansı düşen bu kişilerin yöneticilerden olumsuz davranışlar ve tepkiler görecek olmaları, bu kişilerin örgüte ve işe bağlılıklarını azaltacaktır. Bununla birlikte ilgili literatürde (Blanchard ve Henle, 2008) çalışanların sanal kaytarmayı suiistimal edici olumsuz davranışlarda kullanacağı gibi olumlu amaçlarla da gerçekleştirecekleri belirtilmektedir. Bu noktada örgütteki yöneticilere büyük roller düştüğü açıktır. Yöneticilerin, sanal kaytarmaya yatkın çalışanların bu davranışlarını olumlu yönde sonuç almaya yönelik örgüt politikaları oluşturarak değiştirmeleri gerekliliği aşikârdır.

Araştırmanın kuramsal dayanağını oluşturan Ego Tükenmesi Teorisi'nde de belirtilen çalışanların işlerinden sıkılmaları veya bunalmaları halinde yaptıkları işlerden anlık uzaklaşma istekleriyle sanal kaytarma davranışını bir rahatlama aracı olarak sergiledikleri görülmektedir. Araştırmanın diğer kuramsal dayanağını oluşturan üretkenlik karşıtı iş davranışı teorisinin geri çekilme boyutunda belirtilen çalışanların işlerini yapmaları gereken mesai saatleri içerisinde işleriyle ilgisi olmayan başka uğraşlar bulmaları durumunda da sanal kaytarma yaptıkları görüşüyle bilerek yapılan sanal kaytarma davranışlarının çalışanlarda performans düşüklüğüne neden olarak işe bağlılıklarını da azaltabileceği görülmektedir. 


\section{A. T. Erdem 12/4 (2020) 3843-3858}

Araştırma kapsamında sanal kaytarma davranışının işe bağlılık ve iş performansı etkileşimleri ele alınmaktadır. Bu çerçevede Konya il merkezinde bir bilişim firması çalışanlarına yönelik uygulama yapılmış olup elde edilen bulgular analiz edilerek çeşitli değerlendirmeler yapılmıştır. Literatürdeki çalışmalarda (Cheng vd., 2020; Garrett ve Danziger, 2008) sanal kaytarmanın örgütte yıkıcı etkilere sebep olan sapkın davranışlara neden olduğu belirtilmekle birlikte bu davranışın yıkıcı bir duruma sebebiyet verdiği bilinmektedir. Bu doğrultuda sanal kaytarmanın işe bağlılık ve iş performansını negatif yönde etkilediği düşüncesiyle araştırma hipotezleri kurgulanmıştır.

Araştırma kapsamında işe bağlılığın sanal kaytarma davranışı üzerinde anlamlı bir etkisinin bulunmadığı belirlenmiştir ( $\mathrm{p}=0.179>0.01$ ). Literatürde genel olarak örgütsel bağlılığın sanal kaytarma davranışına etkisini inceleyen (Usman vd., 2019; Niaei vd., 2014; Lim, 2020) araştırmalar olduğu görülmekle birlikte örgüte bağlllık sanal kaytarmayı negatif yönde etkilemektedir. Diğer yandan bu araştırmada işe bağllığın sanal kaytarma üzerinde etkisi ele alınmıştır. Literatürde sanal kaytarma ile işe bağllık etkileşimini inceleyen Rahayuningsih ve Putra (2018) tarafından yapılmış tek araştırmada, Endonezya'daki bir üniversitede görev yapan öğretim görevlilerinin işe bağlılıklarının sanal kaytarma davranışını negatif yönde etkilediğini belirlemişlerdir. Bu kapsamda araştırmadan elde edilen bu bulgu ile literatür örtüşmemektedir.

Araştırmada sanal kaytarmanın iş performansına negatif yönde anlamlı bir etkisinin bulunduğu $(\mathrm{p}<0.01)$ belirlenmiştir. Palladan (2018) öğretim görevlileri üzerinde yaptığ performanısına etkisinin olduğunun belirlemiştir. Özüdoğru ve Yıldırım (2020) hemşirelerin örnekleminde yaptıkları araştırmada sanal kaytarma ile iş perfomansı arasında anlamlı bir ilişki elde etmişlerdir. Literatürdeki bu bilgiler ışığında bu araştırmanın sanal kaytarma ile iş performansı etkileşiminde örtürştügünü göstermektedir.

Araştırmanın üçüncü hipotezinde işe bağlılığın iş performansını poziif yönde etkilediği $(\mathrm{p}<0.01)$ belirlenmiştir. Carmeli ve Freund (2003), avukatlar örnekleminde yaptığı araştırmada katılımcıların işe bağlılık algılarının iş performanslarını pozitif yönde anlamlı olarak etkilediğini belirlemişlerdir. Ampofo (2020), Gana' da faaliyet gösteren otellere yönelik yaptığı araşrtırmada işlerine bağlılık gösteren çalışanların iş performanslarının da yüksek olduğunu belirlemiştir. Bu noktada araştırmanın son hipotezine yönelik elde edilen bulgu ile ilgili literatür paralellik göstermektedir.

Araştırma bulgularından sanal kaytarma ile işe performansı arasındaki ilişkide işe bağlılı̆̆ın aracı rolünün bulunmadığı tespit edilmiştir ( $\mathrm{p}=0.186>0.01$ ). Örgütsel davranış konuları arasında gerek pozitif ve gerekse negatif konularda işe bağlılık kavramının aracı etkisinin araştırıldığı çalışmalarda (Aktaş ve Çetin Gürkan, 2015; Öcel, 2013; Özdemir ve Gören, 2017) işe bağlılığın aracı etkisinin olmadığı belirlenmiştir. Bu kapsamda araştırma bulgusunda da işe bağlılığın aracı etkisi tespit edilememiştir. Bu sonuca göre araştırma bulguları literatürdeki bazı çalışmalarla örtüşmektedir. Diğer yandan işe bağl1lı̆̆ın aracı etkisinin bulunduğu bazı araştırmalarla da (Çetin vd., 2012; Göksel ve Ekmekçioğlu, 2016; E. Kurt, 2013; Sağlam Arı vd., 2010) örtüşmediği belirlenmiştir.

Araştırma bulgularına göre işe bağlılık sanal kaytarma davranışını etkilememektedir. Bu sonuca göre işlerine bağlı olan çalışanların sanal kaytarma davranışından kaçınacakları beklenmesine rağmen işlerine bağlılık duygusu besleyen çalışanların da sanal kaytarma davranışlarında bulunabilecekleri olası bir durumdur şeklinde yorumlanabilir. Başka bir ifadeyle işlerine karşı bağlılık hisseden çalışanların bu davranışlarının sanal kaytarma davranışını yapmamalarında bir önleyici rol oynamamaktadır. Diğer yandan sanal kaytarmanın iş performansını olumsuz yönde etkilediği araştırma bulgularında belirlenmiştir. Bu kapsamda çalışanlar sanal kaytarma ile zamanlarını örgüte yararsız işlerde harcayarak performans düşüklüğüne neden olabileceklerdir yorumu yapılabilir. Son olarak işe bağlılı̆̆ın iş performansını olumlu yönde etkilemesi bulgusuna göre işlerine bağlı olup severek çalışan bireylerin örgütte performanslarının yüksek olabileceğini ve daha özverili çalışabileceklerini gösterdiği şeklinde çıkarsamada bulunabilir.

Araştırma bulgularına göre sanal kaytarmanın iş performansını negatif yönde etkilemesi, bu davranış türünün örgütler için sapkın bir davranış türü olduğunu göstermektedir. Literatürde de yapılmış çalışmalarda (Rahaei, A. ve Salehzadeh, 2020; Wu vd., 2018; Cheng vd., 2020; Wu vd., 2020) sanal kaytarmanın bu noktada sapkın ve yıkıcı bir davranış olduğu belirtilmektedir. Örgütlerin sanal kaytarma davranışını yok etmesi mümkün olmamakla birlikte bu sapkın davranışın yıkıcı sonuçlarını en aza indirmek için hem örgüt çalışanlarının hem de yöneticilerin özverili olması gerekmektedir. Buna ek olarak sanal kaytarma davranışını kısıtlayııı biçimde 


\section{A. T. Erdem 12/4 (2020) 3843-3858}

örgütlerin çalışanları kontrol etmesi, bilişim araçlarını kısıtlamaları ve sanal kaytarmanın verimliliği azaltıcı yönlerine yönelik çalışanların bilinçlendirilmesi öneri niteliğinde sunulabilir.

Çalışma kapsamında Konya il merkezindeki bir bilişim firması çalışanlarına uygulama yapılmıştır. Diğer sektörlere yönelik çalışma yapılmamış olması ve araştırma verilerinin sadece Konya il merkezindeki bir işletmeden toplanması araştırma bulgularının sadece Konya ilinde belirtilen bilişim sektöründeki tek bir işletme ölçeğinde geçerli olduğunu göstermektedir. Gelecekte yapılacak çalışmaların ilgili konularla ve farklı sektörlerde yapılması ve örgütsel davranışın diğer farklı konularının ele alınması öneri niteliğinde olmaktadır.

Sanal kaytarmanın olumlu yönlerine dikkat çeken araştırmalarda bu davranış öğrenmeyi arttırarak çalışanların beceri ve bilgilerinin geliştirilmesine imkân tanınarak bu yolla örgütlerde rekabetin arttırılacağı da belirtilmektedir (Anandarajan vd., 2004; Anandarajan vd., 2000; Blanchard ve Henle, 2008; Sevinç vd., 2012). Bu doğrultuda sanal kaytarmanın olumlu yönlerine yönelik araştırmalar yapılarak literatüre katkı sağlanması önerilmektedir. Diğer yandan bu çalışma kapsamında elde edilen bulgular ile gelecekte yapılacak daha kapsamlı araştırmaların bulguları karşılaştırılarak daha farklı sonuçların elde edileceği düşünülmektedir.

\section{KAYNAKÇA}

Abubakar, A. M., and Ilkan, M. (2016). Impact of online WOM on destination trust and intention to travel: A medical tourism perspective. Journal of Destination Marketing \& Management, 5(3), 192-201.

Akdeniz, T. (2018). Boreout iş performans üzerindeki etkisinde işe bağlllık aracı rolü ve cinsiyet düzenleyici rolü. Aksaray Üniversitesi Sosyal Bilimler Enstitüsü, Yayınlamamış Yükseklisans Tezi. Aksaray

Aktaş, H., ve Çetin Gürkan, G. (2015). İş-aile ve aile-iş çatışması ile bireysel performans etkileşiminde mesleki bağlılığın aracı rolü: Hemşireler üzerinde bir araştırma. Doğuş Üniversitesi Dergisi, 16(2), 139-154.

Anandarajan, M., Devine, P., and Simmers, C. A. (2004). A Multidimensional Sealing Approach to Personal Web Usage in the Workplace. In Personal web usage in the workplace: A guide to effective human resources management (pp. 61-79): IGI Global.

Anandarajan, M., Simmers, C., and Igbaria, M. (2000). An exploratory investigation of the antecedents and impact of internet usage: An individual perspective. Behaviour \& Information Technology, 19(1), 69-85.

Ampofo, E. T. (2020). Mediation effects of job satisfaction and work engagement on the relationship between organisational embeddedness and affective commitment among frontline employees of star-rated hotels in Accra. Journal of Hospitality and Tourism Management, 44, 253-262.

Askew, K., Buckner, J. E., Taing, M. U., Ilie, A., Bauer, J. A., and Coovert, M. D. (2014). Explaining cyberloafing: The role of the theory of planned behavior. Computers in human behavior, 36, 510-519.

Askew, K. L. (2012). The relationship between cyberloafing and task performance and an examination of the theory of planned behavior as a model of cyberloafing. Graduate Theses and Dissertations.

Bakker, A. B., and Albrecht, S. (2018). Work engagement: current trends. Career Development International.

Bakker, A. B., Albrecht, S. L., and Leiter, M. P. (2011). Key questions regarding work engagement. European journal of work and organizational psychology, 20(1), 4-28.

Baron, R. M., and Kenny, D. A. (1986). The moderator-mediator variable distinction in social psychological research: Conceptual, strategic, and statistical considerations. Journal of personality and social psychology, 51(6), 1173.

Bayar, M. (2020). Yalın Yönetim Anlayışının, Çalışanların Görev Performansına Etkilerine Yönelik Bir Araştırma. İşletme Araştırmaları Dergisi, 12(2), 1984-2001.

Bayram, L. (2006). Geleneksel performans değerlendirme yöntemlerine yeni bir alternatif: 360 derece performans değerlendirme. Sayıştay Dergisi, 62, 47-65.

Bayramoğlu, G., Uysal, E., ve Karkı, A. (2020). Öğretmenlerin Algıladıkları Örgütsel Stresin İş Performansı Üzerindeki Etkisinde Duygusal Bağlılığın Aracılık Rolü. Journal of Organizational Behavior Review, 2(2), 115-137.

Baysal, A. C., ve Paksoy, M. (1999). Mesleğe ve örgüte bağlllı̆̆ın çok yönlü incelenmesinde Meyer-Allen modeli. İ̈̈ İsletme Fakültesi Dergisi, 28(1), 7-15. 


\section{A. T. Erdem 12/4 (2020) 3843-3858}

Bekmezci, M., Orçanlı, K., ve Eroğluer, K. (2020). Entelektüel Sermayenin Örgütsel Performansa Etkisinde Bilgi Paylaşımının Düzenleyici Rolü, İşletme Araştırmaları Dergisi, 12 (2), 1585-1604.

Bentler, P. M., and Bonett, D. G. (1980). Significance tests and goodness of fit in the analysis of covariance structures. Psychological bulletin, 88(3), 588.

Blanchard, A. L., and Henle, C. A. (2008). Correlates of different forms of cyberloafing: The role of norms and external locus of control. Computers in human behavior, 24(3), 1067-1084.

Blau, G., Yang, Y., and Ward-Cook, K. (2006). Testing a measure of cyberloafing. Journal of allied health, 35(1), 9-17.

Brett, J. F., Cron, W. L., and Slocum Jr, J. W. (1995). Economic dependency on work: A moderator of the relationship between organizational commitment and performance. Academy of management journal, 38(1), 261-271.

Browne, M. W., and Cudeck, R. (1993). Alternative ways of assessing model fit. Sage focus editions, 154, 136136.

Bülbül, H., ve Demirer, Ö. (2008). Hizmet Kalitesi Ölçüm Modelleri Servqual Ve Serperf'in Karşılaştırmalı Analizi. Selçuk Üniversitesi Sosyal Bilimler Enstitüsü Dergisi(20), 181-198.

Candan, H., ve İnce, M. (2016). Siber Kaytarma Ve Örgütsel Bağlilik Arasindaki Ilişkinin Incelenmesine Yönelik Emniyet Çalişanlari Üzerine Bir Araştirma. Niğde Üniversitesi İktisadi ve İdari Bilimler Fakültesi Dergisi, 9(1), 229-235.

Carmeli, A., and Freund, A. (2003). Work commitment, job satisfaction, and job performance: An empirical investigation. International Journal of Organization Theory \& Behavior.

Cheng, B., Zhou, X., Guo, G., \& Yang, K. (2020). Perceived overqualification and cyberloafing: A moderatedmediation model based on equity theory. Journal of Business Ethics, 164(3), 565-577.

Churchill Jr, G. A. (1979). A paradigm for developing better measures of marketing constructs. Journal of marketing research, 16(1), 64-73.

Çetin, F., Şeşen, H., ve Basım, H. N. (2012). Örgüt kültürünün rol ötesi olumlu davranışlara olan etkisi: Örgütsel bağlılı̆̆ın aracı değişken rolü. Doğuş Üniversitesi Dergisi, 13(2), 197-211.

Çöl, G. (2008). Algılanan güçlendirmenin işgören performansı üzerine etkileri. Doğuş Üniversitesi Dergisi, 9 (1) 2008, 35-46

Erdem, A. T., ve Karadal, H. (2020). Kurumsallaşma, Kurumsal Girişimcilik Ve Örgütsel Yenilikçilik Ilişkilerinin Xy Kuşaklari Açisindan Analizi: Aile Işletmelerinde Bir Araştirma. Bolu Abant İzzet Baysal Üniversitesi Sosyal Bilimler Enstitüsü Dergisi, 20(2), 413-437.

Erdoğan, İ. (1991). İşletmelerde personel seçimi ve başarı değerleme teknikleri,. İ.Ü. İşletme İktisadı Enstitüsü Yayinları.

Eryılmaz, A., ve Doğa, T. (2012). İş Yaşamında Öznel İyi Oluş: Utrecht İşe Bağlllık Ölçeğının Psikometrik Niteliklerinin İncelenmesi. Klinik Psikiyatri Dergisi, 15(1).

Fındıklı, M. A. (2016). Sanal kaytarma ve iş performansı ilişkisi: Sağlık ve tekstil sektörü çalışanlarının karşılaştırılması. International Journal of Social Inquiry, 9(1).

Fornell, C., and Larcker, D. F. (1981). Structural equation models with unobservable variables and measurement error: Algebra and statistics. In: SAGE Publications Sage CA: Los Angeles, CA.

Freudenberger, H. J. (1974). Staff burn-out. Journal of social issues, 30(1), 159-165.

Garrett, R. K., and Danziger, J. N. (2008). On cyberslacking: Workplace status and personal Internet use at work. CyberPsychology \& Behavior, 11(3), 287-292.

Genc, E., ve Aydoğan, E. (2015). İşyerinde Sanal Tembellik Davranışı ve Etkin Zaman Yönetimi İlişkisi: Bir Kamu Kurumunda Arast,trma. Gazi Universitesi Iktisadi ve Idari Bilimler Fakultesi Dergisi, 18(2), 558.

Gezer, H. B., ve Barutçu, E. (2020). Sanal kaytarma ile iş tatmini arasindaki ilişkiye yönelik bir araştırma. Internet Uygulamaları ve Yönetimi Dergisi, 11(1), 35-48.

Göksel, A., ve Ekmekçioğlu, E. B. (2016). Lider-Üye Etkileşiminin Örgütsel Özdeşleşme İle İlişkisinde İşe Bağlılığın Aracı Rolü. Gazi Universitesi Iktisadi ve Idari Bilimler Fakultesi Dergisi, 18(3), 721. 


\section{A. T. Erdem 12/4 (2020) 3843-3858}

Güngör, M. (2016). Sanal kaytarma ve örgütsel bağlllık ilişkisi: kamu ve özel sektör üzerine bir araştırma. Atatürk Üniversitesi Sosyal Bilimler Enstitüsü, Yayınlanmamış Yüksek Lisans Tezi.

Henle, C. A., and Kedharnath, U. (2012). Cyberloafing in the Workplace. In Encyclopedia of cyber behavior (pp. 560-573): IGI Global.

Hollinger, R. C., Slora, K. B., and Terris, W. (1992). Deviance in the fast-food restaurant: Correlates of employee theft, altruism, and counterproductivity. Deviant Behavior, 13(2), 155-184.

Hu, L. t., and Bentler, P. M. (1999). Cutoff criteria for fit indexes in covariance structure analysis: Conventional criteria versus new alternatives. Structural equation modeling: a multidisciplinary journal, 6(1), 1-55.

Hunter, L. W., and Thatcher, S. M. (2007). Feeling the heat: Effects of stress, commitment, and job experience on job performance. Academy of Management Journal, 50(4), 953-968.

İnce, M., ve Özbozkurt, O. B. (2019). İşe Bağlılık İle İş Performansı Arasındaki İlişkide İş Zanaatkârlığının Aracılık Rolü: Zanaatkârlar Üzerine Bir Araştırma. Kocaeli Üniversitesi Sosyal Bilimler Dergisi, 2(38), 6984.

Inzlicht, M., and Schmeichel, B. J. (2012). What is ego depletion? Toward a mechanistic revision of the resource model of self-control. Perspectives on Psychological Science, 7(5), 450-463.

Kahn, W. A. (1990). Psychological conditions of personal engagement and disengagement at work. Academy of management journal, 33(4), 692-724.

Kanten, P. (2012). İşgörenlerde işe adanmanın ve proaktif davranışların oluşumunda örgütsel güven ile örgütsel özdeşleşmenin rolü. SDÜ Sosyal Bilimler Enstitüsü, Doktora Tezi.

Kaplan, M., ve Öğüt, A. (2012). Algılanan örgütsel adalet ile sanal kaytarma arasındaki ilişkinin analizi: hastane çalışanları örneği. İşletme Fakültesi Dergisi, 13(1), 1-13.

Kass, S. J., Vodanovich, S. J., and Callender, A. (2001). State-trait boredom: Relationship to absenteeism, tenure, and job satisfaction. Journal of business and psychology, 16(2), 317-327.

Kim, J. (2012). A longitudinal study on the relationship between workplace harassment and cyberlofing, Yayımlanmamış Yüksek Lisans Tezi. Northern Illinois University.

Kline, P. (2014). An easy guide to factor analysis: Routledge.

Kurt, E. (2013). Algılanan sosyal destek ve iş performansı ilişkisinde işe bağhllı̆̆ın aracı etkisi: Turizm işletmelerinde bir araştırma. Hacettepe Üniversitesi Sosyal Bilimler Enstitüsü İşletme Anabilim Dalı Yüksek Lisans Tezi.

Kurt, M. (2011). Siber Aylaklık Davranışlarının Karşılaştırmalı Olarak İncelenmesi. Paper presented at the Firat University 5th International Computer \& Instructional Technologies Symposium, Elazığ.

Kuznek, E. (2019). Sanal kaytarma ve iş performansı: Kuşaklar teorisi yaklaşımı. Adnan Menderes Üniversitesi Sosyal Bilimler Enstitüsü Yüksek Lisans Tezi,

Kuznek, E., ve Güzel, B. (2019). Sanal Kaytarma ve İş Performansı İlişkisi: Kuşaklar Teorisi Yaklaşımı. Iş̧letme Araştırmaları Dergisi, 11 (4), 2729-2746.

Lewin, A. Y., Sakano, T., Stephens, C. U., and Victor, B. (1995). Corporate citizenship in Japan: Survey results from Japanese firms. Journal of Business Ethics, 14(2), 83-101.

Liberman, B., Seidman, G., Mckenna, K. Y., and Buffardi, L. E. (2011). Employee job attitudes and organizational characteristics as predictors of cyberloafing. Computers in Human Behavior, 27(6), 21922199.

Lim, P.K., Koay, K.Y. and Chong, W.Y. (2020). The effects of abusive supervision, emotional exhaustion and organizational commitment on cyberloafing: a moderated-mediation examination, Internet Research, Vol. ahead-of-print No. ahead-of-print. https://doi.org/10.1108/INTR-03-2020-0165

Lim, V. K. (2002). The IT way of loafing on the job: Cyberloafing, neutralizing and organizational justice. Journal of organizational behavior: the international journal of industrial, occupational and Organizational Psychology and Behavior, 23(5), 675-694.

Lim, V. K., and Chen, D. J. (2012). Cyberloafing at the workplace: gain or drain on work? Behaviour $\mathcal{E}$ Information Technology, 31(4), 343-353.

Liu, E. (2019). Occupational self-efficacy, organizational commitment, and work engagement. Social Behavior and Personality: an international journal, 47(8), 1-7. 


\section{A. T. Erdem 12/4 (2020) 3843-3858}

Loan, L. (2020). The influence of organizational commitment on employees' job performance: The mediating role of job satisfaction. Management Science Letters, 10(14), 3307-3312.

MacKinnon, D. P., Fairchild, A. J., and Fritz, M. S. (2007). Mediation analysis. Annu. Rev. Psychol., 58, 593-614.

Marsh, H. W., \& Hocevar, D. (1985). Application of confirmatory factor analysis to the study of self-concept: First-and higher order factor models and their invariance across groups. Psychological bulletin, 97(3), 562.

McDonald, R. P., and Marsh, H. W. (1990). Choosing a multivariate model: Noncentrality and goodness of fit. Psychological bulletin, 107(2), 247.

Mercado, B. K., Giordano, C., and Dilchert, S. (2017). A meta-analytic investigation of cyberloafing. Career Development International.

Meyer, J. P., Paunonen, S. V., Gellatly, I. R., Goffin, R. D., and Jackson, D. N. (1989). Organizational commitment and job performance: It's the nature of the commitment that counts. Journal of applied Psychology, 74(1), 152.

Mowday, R. T., Porter, L. W., and Dubin, R. (1974). Unit performance, situational factors, and employee attitudes in spatially separated work units. Organizational behavior and human performance, 12(2), 231248.

Niaei, M., Peidaei, M. M., and Nasiripour, A. A. (2014). The relation between staff cyberloafing and organizational commitment in organization of environmental protection. Kuwait Chapter of Arabian Journal of Business and Management Review, 33(2534), 1-13.

Omolade, O., Abdu, M., and Abdul-Qadir, A. B. (2018). Effect of Cyberloafing on Employee Performance among Deposit Money Banks in Kaduna Metropolis. Online Journal Of Arts, Management \& Social Sciences, 3(1).

Öcel, H. (2013). Örgüt kimliğinin gücü, algılanan örgütsel prestij ve kişi-örgüt uyumu ile bağlamsal performans arasındaki ilişkiler: Örgütsel bağlılığın aracı rolü. Türk Psikoloji Dergisi, 28(71), 37-53.

Örücü, E., ve Yildiz, H. (2014). İşyerinde Kişisel İnternet ve Teknoloji Kullanımı: Sanal Kaytarma. Ege Academic Review, 14(1).

Özdemir, M., ve Gören, S. Ç. (2017). Psikolojik güçlendirme, liderlik uyumu ve öğretmen performansı ilişkisinde örgütsel bağlılığın aracı rolü. Elementary Education Online, 16(1).

Özkalp, E., Aydın, U., ve Tekeli, S. (2012). Sapkın örgütsel davranışlar ve çalışma yaşamında yeni bir olgu: Sanal kaytarma (cyberloafing) ve iş ilişkilerine etkileri. Çimento İşveren Sendikası Dergisi, 26(2), 18-33.

Özkan, O. S., ve Omay, T. (2019). Psikolojik Sermayenin Bireysel Performans Üzerindeki Etkisinde BireyÖrgüt Uyumunun Aracılık Rolü: Vakıf Üniversitelerindeki Öğretim Üyelerine Yönelik Bir Araştırma1. İşletme Araştırmaları Dergisi, 743-757.

Özüdoğru, M., ve Yıldırım, Y. T. (2020). Sanal Kaytarma ve İşgören Performansı İlişkisinde İş Stresinin Düzenleyici Etkisinin İncelenmesi: Sağlik Sektöründe Bir Araştırma. Afyon Kocatepe Üniversitesi Sosyal Bilimler Dergisi, 22(2), 467-490.

Palladan, A. A. (2018). Moderating Effects of Cyberloafing Activity on Innovative Work Behaviour and Lecturers Job Performance. International Journal of Advanced Studies in Social Science \& Innovation, 2(1), 28-49.

Polat, Y., ve Dilek, D. (2020). Örgüt Kültürü, Örgütsel Adalet ve İş Tatmini İlişkisi Üzerine Bir Araştırma. İşletme Araştırmaları Dergisi, 2020, 12(2), 1267-1284.

Polatçı, S., Özçalık, F., ve Cindiloğlu, M. (2014). Üretkenlik karşıtı iş davranışı ve örgütsel vatandaşlık davranışı üzerinde kişi-örgüt uyumunun etkileri. Ömer Halisdemir Üniversitesi İktisadi ve İdari Bilimler Fakültesi Dergisi, 7(3), 1-12.

Rahaei, A., and Salehzadeh, R. (2020). Evaluating the impact of psychological entitlement on cyberloafing: the mediating role of perceived organizational justice. Vilakshan-XIMB Journal of Management.

Rahayuningsih, T., and Putra, A. A. (2018). Impact of adversity intelligence and work commitment on cyberloafing behavior. Couns-Edu: The International Journal of Counseling and Education, 3(2), 69-72. 


\section{A. T. Erdem 12/4 (2020) 3843-3858}

Randall, D. M. (1987). Commitment and the organization: The organization man revisited. Academy of management Review, 12(3), 460-471.

Roberts, D. R., and Davenport, T. O. (2002). Job engagement: Why it's important and how to improve it. Employment Relations Today, 29(3), 21.

Rose, R. C., Kumar, N., and Pak, O. G. (2009). The effect of organizational learning on organizational commitment, job satisfaction and work performance. Journal of Applied Business Research (JABR), 25(6).

Runing S, H. S., and Cahyadin, M. (2012). The Moderation Effect Of Commitment To Supervisor And Internet Expertise On Work Stressor And Employee Cyberloafing: The Study On Employee Of Local Government Of Surakarta. Journal of Indonesian Economy \& Business, 27(2).

Saghih, A. M. F., \& Nosrati, S. (2020). The antecedents of job embeddedness and their effects on cyberloafing among employees of public universities in eastern Iran. International Journal of Islamic and Middle Eastern Finance and Management.

Sağlam Arı, G., Bal, H., ve Çına Bal, E. (2010). İşe Bağlılığın Tükenmişlik Ve İşten Ayrılma Niyeti İlişkisindeki Aracılık Etkisi: Yatırım Uzmanları Üzerinde Bir Araştırma. Süleyman Demirel Üniversitesi İktisadi ve İdari Bilimler Fakültesi Dergisi, 15(3), 143-166.

Schaufeli, W. B., Salanova, M., González-Romá, V., and Bakker, A. B. (2002). The measurement of engagement and burnout: A two sample confirmatory factor analytic approach. Journal of Happiness studies, 3(1), 71-92.

Schaufeli, W. B., Taris, T. W., and Van Rhenen, W. (2008). Workaholism, burnout, and work engagement: Three of a kind or three different kinds of employee well-being? Applied psychology, 57(2), 173-203.

Serinikli, N. (2020). Sağlık Çalışanlarında İş Özerkliği ve İş Performansı Arasındaki İlişkide Örgütsel Sinizm ve Yaşam Tatmini Seri Çoklu Arabuluculuğu. İşletme Araştırmaları Dergisi, 12(2), 1693-1711.

Sevinç, K., Lale, O., ve Türesin, H. (2012). İş yaşaminda sosyal kolaylaştirma kavrami ve sanal kaytarma ile ilişkisi: Araştirma görevlileri üzerinde bir araştirma. Sosyal ve Beşeri Bilimler Dergisi, 4(1), 287-295.

Sigler, T. H., and Pearson, C. M. (2000). Creating an empowering culture: examining the relationship between organizational culture and perceptions of empowerment. Journal of quality management, 5(1), 27-52.

Starnes, B. J., and Truhon, S. A. (2006). A primer on organizational commitment. Human Development and Leadership Division.

Spector, P. E., Fox, S., Penney, L. M., Bruursema, K., Goh, A., ve Kessler, S. (2006). The dimensionality of counterproductivity: Are all counterproductive behaviors created equal?. Journal of Vocational Behavior, 68(3), 446-460.

Supriyanto, A. S. (2013). Role of procedural justice, organizational commitment and job satisfaction on job performance: The mediating effects of organizational citizenship behavior. International Journal of Business and Management, 8(15), 57-67.

Syamsir, S. (2020). Competence, Job Satisfaction, Work Motivation, and Job Performance of The Village ("Nagari") Masters in Managing E-Village Finance. International Journal of Advanced Science and Technology, 29(8), 1337-1350.

Tanaka, J. S., and Huba, G. J. (1985). A fit index for covariance structure models under arbitrary GLS estimation. British Journal of Mathematical and Statistical Psychology, 38(2), 197-201.

Tutar, H. (2000). Küreselleşme sürecinde işletme yönetimi: Hayat Yayınları.

TÜİK, T. İ. K. (2018a). Girişimlerde bilişim teknolojileri kullanım araştırması. TÜİK haber bülteni, Sayı: 27820.

TÜIK, T. İ. K. (2018b). Hanelerde bilişim teknolojileri kullanımı. http://www.tuik.gov.tr/PreTablo.do?alt_id=1028 (Erişim Tarihi: 12.04.2020).

TÜİK, T.İ.K. (2019). Hanehalkı Bilişim Teknolojileri Kullanım Araştırması,

http://www.tuik.gov.tr/PreTablo. do?alt_id=1028 (Erişim Tarihi: 05.08.2020).

Ugrin, J. C., and Pearson, J. M. (2013). The effects of sanctions and stigmas on cyberloafing. Computers in human behavior, 29(3), 812-820. 
Usman, M., Javed, U., Shoukat, A., and Bashir, N. A. (2019). Does meaningful work reduce cyberloafing? Important roles of affective commitment and leader-member exchange. Behaviour \& Information Technology, 1-15.

Vitak, J., Crouse, J., and LaRose, R. (2011). Personal Internet use at work: Understanding cyberslacking. Computers in Human Behavior, 27(5), 1751-1759.

Wagner, D. T., Barnes, C. M., Lim, V. K., and Ferris, D. L. (2012). Lost sleep and cyberloafing: Evidence from the laboratory and a daylight saving time quasi-experiment. Journal of Applied psychology, 97(5), 1068 1076.

Ward, E. A., and Davis, E. (1995). The effect of benefit satisfaction on organizational commitment. Compensation and Benefits Management, 11, 35-35.

Williams, L. J., and Anderson, S. E. (1991). Job satisfaction and organizational commitment as predictors of organizational citizenship and in-role behaviors. Journal of Management, 17(3), 601-617.

Wright, T. A. (1997). Job performance and organizational commitment. Perceptual and Motor Skills, 85(2), 447450 .

Wu, J., Mei, W., and Ugrin, J. C. (2018). Student cyberloafing in and out of the classroom in China and the relationship with student performance. Cyberpsychology, Behavior, and Social Networking, 21(3), 199-204.

Wu, J., Mei, W., Liu, L., \& Ugrin, J. C. (2020). The bright and dark sides of social cyberloafing: Effects on employee mental health in China. Journal of Business Research, 112, 56-64.

Yavuzkılıç, S. (2020). Bağımsız anaokullarında görev yapan okul öncesi öğretmenlerinin örgütsel bağhllıkları ile iş performansları arasındaki ilişki. Pamukkale Üniversitesi Eğitim Bilimleri Enstitüsü, Yükse Lisans Tezi.

Yorulmaz, M., ve Karabacak, A. (2020). Liman Çalışanlarında Örgütsel Güven ile İş Performansı Arasındaki İlişki: İş Tatmini ve Örgütsel Bağlllığın Rolü. Balkan and Near Eastern Journal of Social Sciences, 2020: 06 (02), 121-130.

Yousef, D. A. (2000). Organizational commitment: a mediator of the relationships of leadership behavior with job satisfaction and performance in a non-western country. Journal of managerial Psychology. 